\section{Review of Inflammation and Infection in Contact Lens Wearers: Risk Factors and Association with Single Nucleotide Polymorphisms}

Inflammatory corneal complications associated with contact lens (CL) wear range from self limiting sterile corneal infiltrative conditions such as infiltrative keratitis (IK), and contact lens-induced acute red eye (CLARE) to severe sight threatening microbial keratitis [1-3]. In practice, managing complications associated with CL wear has been a challenge to practitioners, especially in diagnosing and treating cases such as early microbial keratitis [1]. In addition, selflimiting conditions such as CLARE and IK can cause temporary discomfort to the wearer, and may lead to the discontinuation of CL wear.

\section{Microbial Keratitis \& Corneal Inflammatory Events}

\section{Microbial keratitis}

Microbial keratitis (MK; Figure 1A), a potentially blinding disease, is defined as an inflammation of the corneal tissue characterised by an epithelial defect associated with stromal infiltration, tissue necrosis and stromal loss, due to direct infection by microbial agents such as bacteria, fungi, amoeba and viruses [4]. The infiltrate can appear as large, irregular-edged focal infiltrates located mainly in the central or paracentral region surrounded by small satellite lesions. Diffuse infiltrates are seen in the anterior to deep stroma. Symptoms such as pain, redness, lid oedema, increased lacrimation, photophobia, discharge and vision loss are reported in these cases [3]. MK can occur with or without CL wear. Bacteria are common causative agents during CL wear, but other microbes including fungi and Acanthamoeba can cause the disease [5,6]. The annual incidence of contact lens-associated microbial keratitis varies between 2.2 to 6.9 per 10,000 wearers with daily wear (DW) hydrogel contact lenses, 9.3 to 20.9 per 10,000 wearers with extended wear (EW) hydrogel contact lenses, and 18 to 19.8 per 10,000 wearers with silicone hydrogel (SiHy) lenses on EW schedule [7-10]. For non-CL keratitis cases the rate has been reported to be $14(11.7-16.6)$ per 100,000 people [11,12]. Thus, the best estimate of the increased risk of MK with contact lens wear is that CL wear is approximately a 10 times increased risk.

Contamination of contact lenses by various types of microbes is probably the first step in the production of contact lens-associated MK (CL-MK). For non CL-MK, trauma of the cornea is important $[11,13,14]$. In CL-MK the most common causative microbe is Pseudomonas aeruginosa (P. aeruginosa) [8,15], whereas for non CL-MK staphylococci are commonly isolated $[14,16]$. P. aeruginosa infection is promoted by its ability to produce proteases, to either invade or kill corneal cells, and the excessive activation of host defense systems [17-20]. Lipopolysaccharide (LPS) can aid the microorganism in adhering to the cornea or contact lenses [21-23].

\section{Journal of}

\section{Ocular Biology}

\author{
Nagaraju Konda ${ }^{1,2}$ and Mark DP Willcox ${ }^{1^{*}}$

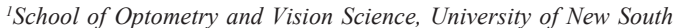 \\ Wales, Australia \\ ${ }^{2}$ Brien Holden Vision Institute, Sydney, Australia \\ *Address for Correspondence \\ Mark DP Willcox, PhD, FBCLA, FAAO, MSAM, Professor, School of \\ Optometry and Vision Science, The University of New South Wales, \\ Sydney, NSW 2052, Australia, Tel: +61293854164; Fax: +61293136243; \\ E-mail:mdpwillcox@gmail.com
}

Submission: 15 August 2013

Accepted: 28 September 2013

Published: 02 October 2013

Reviewed \& Approved by: Dr. Anuj Chauhan, Department of Ophthalmology, University of Florida, USA

Toll-like receptors (TLRs) recognise LPS of $P$. aeruginosa and activate the innate immune system to produce inflammatory mediators [24]. The continued presence of these inflammatory mediators, such as interleukins, chemokines, and proteases, in cases of MK leads to corneal tissue destruction and vision loss. Application of broad spectrum antibiotics regularly, such as monotherapy with a fluoroquinolone or dual therapy with aminoglycoside/cephalosporin combination, is the safest management strategy [25].

\section{Contact lens-induced peripheral ulcer}

Contact lens-induced peripheral ulcer (CLPU; Figure 1B) is defined as an inflammatory condition of the cornea characterised in its active stage by focal excavation of the epithelium, infiltration, and necrosis of the anterior stroma [26]. There is a single, circular, well-defined, and dense infiltrate up to $2 \mathrm{~mm}$ in size with slight to moderately dense diffuse cellular reaction surrounding the focal infiltrate (in the mid-periphery to periphery of the anterior corneal stroma) [3]. A full thickness break in the corneal epithelium overlying the focal infiltrate is seen in $83.7 \%$ of cases and occasionally a slight anterior chamber cellular reaction is observed (in $25 \%$ of cases). This condition causes severe to moderate pain and discomfort to the wearer or could be asymptomatic.

Gram-positive bacteria such as Staphylococcus aureus (S. aureus) and Streptococcus pneumonia have been isolated from lenses at the time of an event and it is hypothesised that their release of toxins may provoke the development of CLPU [27-29]. Wu et al. reported that CLPU-like lesions can be produced in the rabbit eye in the presence of an epithelial defect and contact lenses contaminated with S. aureus

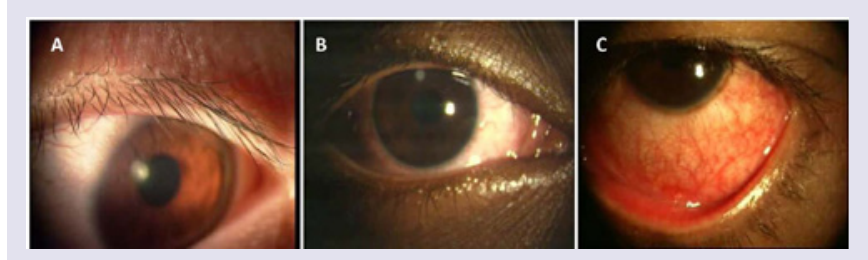

Figure 1: Infiltrative responses during contact lens wear. (A) microbial keratitis during contact lens wear. Note the small ulcer towards the periphery of the cornea. There was infiltration of the cornea and marked hyperaemia of the conjunctiva. (B) Contact lens peripheral ulcer. NOte ulcer at top of the cornea. (C) Contact lens-induced red eye. No ulceration, but conjunctival hyperaemia and corneal infiltration. 
Citation: Konda N, Willcox MDP. Review of Inflammation and Infection in Contact Lens Wearers: Risk Factors and Association with Single Nucleotide Polymorphisms. J Ocular Biol. 2013;1(2): 9.

[30]. Histological examination of biopsies taken from the affected site of CLPUs revealed an intact Bowman's layer with overlying epithelial disruption and an inflamed stroma with dense infiltration of PMNs [26,31]. The incidence of CLPU in disposable EW modality ranges from 1.6 to $2.9 \%$ in Australia and 13\% per year in India [32]. Sweeney et al. reported that about $21 \%$ of events were resolved within 7 days and the remaining events were completely resolved in 2 to 3 weeks' time leaving a dense circular scar corresponding to the area of focal infiltrate [3]. Treatment involves temporary discontinuation of lens wear with frequent follow up visits and can involve prophylactic antibiotic therapy. Unpreserved unit dose saline, cold compresses, and analgesics have been used as an alternate treatment to decrease patient symptoms. CLPUs have not been associated with vision loss. However, as it may be difficult to differentiate early MK from CLPU, it is advisable to also treat with antibiotics [1].

\section{Contact lens-induced acute red eye}

Contact lens-induced acute red eye (CLARE; Figure 1C) is an inflammatory condition of the cornea and the conjunctiva following the use of extended wear contact lenses. CLARE has been reported to present with diffuse congestion of the bulbar and limbal conjunctiva, small multiple focal and diffuse infiltrates in the mid-periphery to periphery of cornea with or without punctate staining overlying the infiltrate $[3,33]$. Sweeney et al. reported that the redness and infiltration resolved within 3 to 14 days of ceasing CL wear [3].

CLARE is produced when Gram-negative bacteria, including Pseudomonas sp. [34] colonise the lens probably then releasing toxins and other products which, when combined with the pro-inflammatory state of the closed eye during the contact lens wear, lead to signs and symptoms of CLARE [35-37]. The incidence of CLARE has been reported to be $12 \%$ and $1.4 \%$ in India and Australia respectively [32] Twenty nine percent of subjects have been reported to have recurrent CLARE [38]. CLARE is a self-limiting condition and can be managed with temporary discontinuation of lens wear and lubricating eye drops with close follow-ups [3]. Topical corticosteroids can be prescribed if there is no improvement in the condition and symptoms persists [39].

\section{Infiltrative keratitis}

Infiltrative keratitis (IK) is a relatively mild inflammatory reaction of the cornea characterised by anterior stromal infiltration, with or without epithelial involvement, in the mid-periphery to periphery of the cornea [3]. Infiltrates in this condition can be small and multiple, with or without accompanying mild to moderate diffuse infiltration $[3,40]$. In the majority of these events, the corneal epithelium is not involved or has only punctate fluorescein staining. Foreign bodies trapped beneath the lens, tightly fitting soft contact lenses, or bacterial toxins are thought to be the causative factors for this condition. In many cases, exotoxins of Staphylococcus sp. or Streptococcus sp. are hypothesised to contribute to the disease [34]. IK can be managed by discontinuing the lens wear temporarily for 1 or 2 weeks. Unit dose saline is prescribed to alleviate symptoms $[2,41]$.

Risk Factors for Microbial Keratitis and Corneal Inflammatory Events Associated with Contact Lens Wear

\section{Risk factors of contact lens- associated microbial keratitis}

Risk factors of CL-MK are overnight use [42], younger age [43], male gender [7], infrequent lens disinfection [42], living in a warm climate [44] and non-compliance with lens hygiene practices [10]. Several reports have been published to study the variables associated with severity of contact lens-associated microbial keratitis and to differentiate sterile ulcers from infectious events by scoring clinical parameters such as vision loss, and infiltrate location $[1,45,46]$. In addition, variables such as anterior chamber (AC) reaction [1], time taken to presentation at an appropriate clinic [43], and hospital admission $[8,47]$ play an important role in defining the severity of these cases. Risk factors associated with CL-MK are listed in Table 1 [48-52].

Most of these risk factors have been identified from studies investigating the efficacy of either contact lenses or lens care products from prospective clinical trials. The most common risk factor was wearing lenses on EW schedule compared to wearing lenses on a daily wear schedule. Vision loss was reported to be approximately $14 \%$ of wearers in CL-MK cases [53]. Greater than two lines vision loss was reported in patients using soft hydrogel and SiHy contact lenses on DW (17\% \& 10\%) and EW (27\% \& 20\%) respectively [45]. In a series of cases studying wear of SiHy lenses in Australia, none of the participants lost 2 or more lines of best corrected VA [53], whereas a study from Sweden has reported that 3 out of twenty-six cases using low-Dk conventional hydrogel contact lenses worn on an EW basis lost 2 or more lines of VA [54]. Similarly, Cheng et al. have reported that 12 out of 92 people wearing DW rigid gas permeable, soft hydrogel lenses or EW hydrogel lenses lost 2 or more lines of VA [8]. Edwards et al. found that delay in seeking treatment was the only independent risk factor for vision loss and reported that those cases had 4.5 times higher risk of losing 2 or more lines of VA [43].

\section{Risk factors of contact lens-induced sterile keratitis}

The incidence of sterile keratitis has ranged from 2.0 to $6.6 \%$ in randomised control trials [55-57], and 5.7 to $44.4 \%$ in non-

Table 1: Some risk factors associated with contact lens microbial keratitis in recent epidemiology studies.

\begin{tabular}{|l|c|c|}
\hline Risk Factors of Microbial Keratitis & $\begin{array}{l}\text { Relative } \\
\text { risk or } \\
\text { Odds ratio }\end{array}$ & References \\
\hline $\begin{array}{l}\text { Wearing lenses for more number of days per } \\
\text { week (<2 compared to 3-5) }\end{array}$ & 3.46 & {$[48]$} \\
\hline Extended wear compared to daily wear & 5.28 & {$[49]$} \\
\hline New to extended wear & 4.42 & {$[49]$} \\
\hline Hypermetropia compared to myopia & 1.77 & {$[48]$} \\
\hline $\begin{array}{l}\text { Poor hand hygiene (not always washing hands } \\
\text { prior to handling lenses) }\end{array}$ & 1.49 & {$[48]$} \\
\hline Poor lens case hygiene & 3.70 & {$[50]$} \\
\hline $\begin{array}{l}\text { Use of particular multipurpose disinfecting } \\
\text { solutions: }\end{array}$ & & {$\left[\begin{array}{l}\text { For general MK (Complete Comfort Plus, } \\
\text { Advanced Medical Optics, Inc; Santa Ana, CA, } \\
\text { USA }\end{array}\right.$} \\
$\begin{array}{l}\text { For Fusarium keratitis (ReNu Moisture Loc, } \\
\text { Bausch + Lomb, Rochester, NY, USA }\end{array}$ & 13.3 & {$[51]$} \\
\hline $\begin{array}{l}\text { For Acanthameoba keratitis (Complete Moisture } \\
\text { Plus, Advanced Medical Optics) }\end{array}$ & 16.67 & {$[52]$} \\
\hline $\begin{array}{l}\text { Replacing lens cases less frequently than every } \\
\text { 6 months }\end{array}$ & 5.39 & {$[50]$} \\
\hline \begin{tabular}{l} 
Purchasing lenses on the internet/mail order \\
\hline Smoking
\end{tabular} & 4.76 & {$[49]$} \\
\hline
\end{tabular}


Citation: Konda N, Willcox MDP. Review of Inflammation and Infection in Contact Lens Wearers: Risk Factors and Association with Single Nucleotide Polymorphisms. J Ocular Biol. 2013;1(2): 9.

randomised clinical trials $[32,58]$ per 100 wearers per year. The difference in the incidence rates between the studies have been attributed to environmental conditions, and higher habitual levels of bacterial colonisation of contact lenses [59]. However, these reports may underestimate the total incidence because of the self-limiting nature of these conditions. Associated risk factors vary between microbial and sterile keratitis. Risk factors associated with sterile keratitis are listed in Table 2 [60,61]. For sterile keratitis, the risk of infiltrates appears to be higher during the adaptation period and in those wearing lenses for shorter duration [62]. In an interventional study reported by Ozkan et al. participants working in "non-ideal" environments such as exposure to wind, dust, fumes and water splashes had a higher incidence of inflammatory events compared to the subjects working in more "ideal" environments such as office workers [61]. High levels of contact lens microbial contamination or corneal vascularisation increased the risk of having an inflammatory event by 2.78 and 12.33 times compared to participants with a mean cfu/lens of $1.45 \log$ contamination and no corneal vascularisation respectively [61].

\section{Host molecular factors involved in keratitis}

Most studies using animal models have failed to generate infections in the cornea without first damaging the corneal surface (usually through scratching with a needle). For example, studies using guinea pigs have not been able to produce corneal infections while wearing contact lenses contaminated with $P$. aeruginosa [63] even with high levels of a known infective strain of $P$. aeruginosa adherent to the lenses before wear $\left(1-5 \times 10^{6}\right.$ cells per lens). Infections could only be initiated after producing an epithelial defect. However, Zhang et al. and Tam et al. have shown that it is possible to produce infections during lens wear in rat eyes without prior corneal damage $[64,65]$. However, Zhang et al. had to use high numbers of bacteria applied regularly to the lens wearing eye over many days [64]. These conditions might not mimic those found with humans, as CL-MK can occur even after only one day of lens wear. Both models used rats, which blink much less frequently than humans (unpublished observations) and so may not be entirely comparable to the human situation.

Toll-like receptors: During the process of bacterial adhesion to corneal cells, or as a result of bacterial interactions with defence

Table 2: Risk factors of sterile keratitis associated with daily and extended contact lens wear in recent epidemiology studies and clinical trials.

\begin{tabular}{|l|c|c|}
\hline Risk factors of sterile keratitis & $\begin{array}{l}\text { Relative } \\
\text { risk or } \\
\text { Odds ratio }\end{array}$ & References \\
\hline $\begin{array}{l}\text { CL wearing experience (<3 years compared to } \\
\text { 3-5 years) }\end{array}$ & 1.6 & {$[60]$} \\
\hline Overnight lens wear & $\geq 1.6$ & {$[60]$} \\
\hline Days of CL wear per week ( $\leq 2$ compared to $\geq 3)$ & $\geq 2.3$ & {$[60]$} \\
\hline $\begin{array}{l}\text { Silicone hydrogel compared to regular } \\
\text { replacement soft lenses }\end{array}$ & 2.0 & {$[60]$} \\
\hline $\begin{array}{l}\text { DAILIES lenses (CIBA Vision, Atlanta, GA. USA) } \\
\text { compared to regular replacement soft lenses }\end{array}$ & 2.7 & {$[60]$} \\
\hline Hand washing before lens handling (not always) & 1.9 & {$[60]$} \\
\hline Steep lens fitting & 1.8 & {$[61]$} \\
\hline Bacterial contamination of contact lenses & 2.8 & {$[61]$} \\
\hline Smoking & 1.5 & {$[60]$} \\
\hline
\end{tabular}

proteins in tears and release of bacterial products, corneal cells respond to the presence of bacteria. There are various recognition systems that the host can employ to signal microbial challenge, and one such system is collectively known as pattern recognition receptors (PRRs) that recognise pathogen-associated molecular patterns (PAMPs) or damage-associated molecular patterns (DAMPs) [66]. Tolllike receptors (TLRs) are class I integral membrane glycoproteins, that recognise PAMPs that are expressed on infectious agents, and mediate the production of cytokines necessary for the development of effective immunity [67].

In humans there are several TLRs, but the most important in terms of bacterial keratitis (or sterile keratitis as the result of microbial colonisation of contact lenses without frank infection) are probably TLR2, TLR4, TLR5 and TLR9. Each of these recognises a specific PAMP [68]. Once the TLRs have bound to their respective ligands a series of intracellular signals occurs that leads to the up-regulation of expression of a range of inflammatory and defence mediators such as defensins and cytokines. There are contradicting statements in the literature about surface localisation of these receptors on the corneal epithelium [69-71] and their response to bacterial ligands [72-74]. Takeuchi et al. showed that $S$. aureus peptidoglycan-induced cytokine production was dependent on TLR2 [75]. Synthetic lipopeptide, Pam3Cys, a known TLR2 agonist has been reported to stimulate the NF-kB pathway and to activate pro-inflammatory cytokine response and human beta defensins-2 gene up-regulation in vitro, in human corneal epithelial cells (HCECs) [71,76].

LPS activates pro-inflammatory cytokine production through stimulation of TLR4. Poltorak, Arbour and other colleagues have reported that TLR4 is an essential component of the LPS receptor complex [77-79]. Poltorak et al. reported that resistance of $\mathrm{C} 3 \mathrm{H} /$ $\mathrm{HeJ}$ or C57B1/10ScCr mice to LPS was due to mutation in the TLR4 gene [79]. In the LPS-nonresponsive mouse strain, $\mathrm{C} 3 \mathrm{H} / \mathrm{HeJ}$, a point mutation in the TIR (Toll-IL-1 receptor) domain of TLR4 is responsible for a defect in LPS signal transduction. Another mouse strain, B10.ScCR that does not respond to LPS lacks the entire TLR4 gene.

There is likely to be a highly controlled interplay between TLR stimulation of the pro-inflammatory response during acute infection, and TLR stimulation of defence responses that may operate to protect the cornea from inflammation. Single Ig IL-1R-related molecule (SIGIRR) is a regulator of the TLR response that sequesters important adaptor molecules such as MyD88 from interaction with TLRs and it inhibits TLR4 signalling [80]. SIGIRR reduces the production of TLR4, and the cytokines IL-18, IFN $\gamma$, IL-1 $\beta$ and MIP-2 [80]. Another transmembrane protein ST2 also sequesters adaptor molecules such as MyD88. ST2 is the receptor for IL-33. ST2 alters the pattern of cytokine responses in mouse corneas during infection with $P$. aeruginosa, up-regulating IL-10, IL-4, and IL-5, down-regulating IL-1 $\beta$, MIP-2, IL-6 and IFN $\gamma$, resulting in decreases in bacterial and neutrophil numbers during infection $[80,81]$.

TLR5 detects Gram negative bacterial flagellin from both Gram-positive and Gram-negative bacteria [82] and elicits an epithelial response by activating the NF-kB pathway and releasing inflammatory cytokines such as IL-6 and IL-8 in intestinal and corneal epithelial cells $[83,84]$. TLR9 recognises CpG (cytosine and guanine separated by only one phosphate) sequence in DNA to mount an immune response [85]. CpG DNA stimulates B cells, 
macrophages and dendritic cells to secrete cytokines such as IL12 [86]. TLR9 gene knockout mice have been shown to be completely defective in their response to CpG DNA, including lacking cytokine production [69]. This indicates that TLR9 plays an essential role in the cellular response to CpG DNA.

Cytokines and chemokines: After TLRs are activated, they stimulate the production of various mediators of the host defence and inflammation response. These include various cytokines and chemokines as outlined above. Cytokines are small proteins produced by most cell types and are used to signal effects, such as invasion/infection, and to stimulate the receiving cell to produce a set of responses including production of more cytokines and defense molecules, and the overall inflammation response. Chemokines direct the recruitment of white blood cells to the sites of infection and inflammation. Several inflammatory mediators, particularly cytokines such as IL- 6 and the neutrophil chemotactic factor IL- 8 are altered during contact lens wear [35]. Contact lens wear also reduces the numbers of neutrophils that can enter into the tear film during sleep [87]. This, along with increases in the numbers of microbes on the eye during sleep [87], potentially contributes to the increased risk of CL-MK seen during extended wear of lenses.

Both susceptible B6 and resistant BALB/c mice have elevated levels of IL-1 after $P$. aeruginosa infection. However, the prolonged elevated levels of IL-1 in B6 mice results in PMNs infiltration and corneal perforation but the controlled IL-1 production of Balb/c mice results in more limited infiltration of PMNs but with bacterial clearance [88]. IL-1 $\beta$ is a major pro-inflammatory cytokine produced during microbial keratitis in animals [88-91]. IL-6 may be involved in downregulating corneal inflammation and the resolution of disease [92]. IL-6 gene knockout mice showed more severe $P$. aeruginosa keratitis [93] and if IL-6 is given to mice by injection during $P$. aeruginosa infection in the eye, the animals show better disease progression [94]. Similar results were reported with S. aureus in IL-6 gene knockout mice [95]. IL-10 is predominantly produced by a subset of infiltrating white blood cells during $P$. aeruginosa keratitis and as such mediates its effects later in the infection. IL-10 may be involved in preventing excessive angiogenesis during $\mathrm{MK}$, thereby controlling vision loss during infection [93].

There have been a few studies examining the tears of people with sterile keratitis such as CLARE and CLPU $[96,97]$ and the murine corneal response to mild keratitis caused by strains of $P$. aeruginosa isolated from CLARE and unable to infect the cornea [98]. These have shown that in humans CLARE responses are associated with production of IL-8, GM-CSF and the lipid inflammatory mediator $\mathrm{LTB}_{4}$, whereas tears collected from subjects with CLPU had increased levels of LTB but not IL-8 or GM-CSF $[96,97]$. In the murine model, the $P$. aeruginosa strain from CLARE could stimulate the production of IL- $1 \beta$ and IL-6, but to a lower level than the strains of $P$. aeruginosa that were able to cause frank infection of the cornea [98].

Defensins and other cationic peptides: A number of cationic antimicrobial peptides (AMPs) have been identified in human corneal and conjunctival epithelial cells such as human $\beta$-defensin (DEFB) $-1,-3$ and cathelicidin (LL-37). Huang et al. have reported that LL-37 knock-out mice showed increased susceptibility to infection with $P$. aeruginosa and also exhibited differential expression of protein levels of IL-1 $\beta$ and IL-6 [99]. Redfern et al. showed that activation of TLRs by their respective agonists resulted in the production of antimicrobial peptides, in particular of LL-37 which in turn may work in combination with other antimicrobial proteins in tears (such as lysozyme) to kill invading pathogens [100]. Kumar et al. have noted that pre-exposure to TLR5 ligand, impaired activation of the signalling pathway and reduced the production of IL-8 and TNF- $\alpha$ in C57BL/6 mice and markedly reduced the $P$. aeruginosa infection by up regulating the hBD2 and LL-37 [101]. In addition to their antimicrobial effects, defensins have been shown to modulate a variety of cellular activities including stimulation of cytokine production [102], and stimulation of histamine release from mast cells [103]. Huang et al. reported that LL-37 can induce human corneal epithelial cell (HCEC) migration and secretion of IL-8, IL-6, and IL-1 $\beta$ and TNF- $\alpha$ [104]. There have been no studies examining the defensin response to mice corneas challenged with as strain of $P$. aeruginosa isolated from a CLARE response or any other sterile keratitis.

\section{Single Nucleotide Polymorphisms (SNPs)}

As outlined above, many studies in mice have demonstrated that certain TLRs, cytokines and chemokines, as well as defense proteins are critical to the outcome of keratitis caused by bacteria. As replicating these studies in humans are impossible, people have examined whether changes to the genes of these molecules might be related to disease. There are number of studies investigating the association between genetic variants and disease states. Diseases such as cancer, heart disease, diabetes and diseases associated with mucosal tissues such as periodontitis and airway infection are influenced by genetic variants in many genes [105-111]. Single nucleotide polymorphisms (SNPs) are most commonly single base differences in DNA among individuals. Each individual's genetic material contains a unique SNP pattern that is made up of many different variations. A SNP is considered monomorphic if a single form or allele is identified in the population of interest or polymorphic if more than one form or allele is identified in the population of interest. SNPs may not be directly responsible for a disease state, instead, they can be used to identify genes encoding key cell signalling or inflammatory mediators that cause differences in gene function or regulation that then directly contribute to disease processes [112-114].

The most obvious polymorphisms are missense or nonsynonymous polymorphisms in which the allele differences code for a different amino acid in a protein. This can result in a non-functional protein being translated that is responsible for causing diseases such as Alzheimer's [115]. However, not all missense mutations lead to functional protein change. For example, an amino acid which is replaced by different amino acid of similar chemical properties may still allow the protein to function normally. In synonymous polymorphisms, mutation alters the deoxyribonucleic acid (DNA) sequence but doesn't alter the amino acid translation. For example, codons TTA and TTG encode for the amino acid leucine. The base in position 3 of a TTA codon is replaced by G, leaving the codon as TTG. The amino acid at this position in the protein will remain as leucine. SNPs at splice sites result in variant proteins that differ in the axons they contain, and SNPs at promoter regions are reported to affect the regulation and expression of protein $[111,116]$.

When SNPs are associated with other SNPs because of linkage disequilibrium, they may all be associated with a disease or phenotype, even though only one or a few may directly affect the phenotype [117]. Analysis of the association of human disease with SNPs shows 
Citation: Konda N, Willcox MDP. Review of Inflammation and Infection in Contact Lens Wearers: Risk Factors and Association with Single Nucleotide Polymorphisms. J Ocular Biol. 2013;1(2): 9.

evidence of particular genes/proteins with diseases. SNPs in cytokine genes can result in imbalances in the cytokine milieu by affecting transcriptional activity, protein production, receptor binding, or functional activity. SNPs in coding regions of the gene can interfere with protein transcription and translation by altering amino acid sequences and subsequent protein structure which can result in a non-functional protein. SNPs in the promoter or regulatory regions of gene may alter transcriptional activity.

\section{SNPs and Toll-like receptors (TLRs) 2, 4, 5, and 9}

One of the known TLR2 non-synonymous SNPs, rs5743708, has been reported to be associated with an increased susceptibility to Gram positive bacterial infection $[118,119]$. One known TLR4 missense mutation, rs4986790, alters the extracellular domain of TLR4, attenuates the TLR4 signalling pathway, diminishes the inflammatory response to Gram-negative pathogens, and is associated with a diminished airway response to inhaled LPS in healthy volunteers [120]. Several other studies have reported the prevalence of mutations in TLR4 that can alter human pathophysiology $[121,122]$. Ferwerda et al. reported that a TLR4 haplotype that alters the cytokine response to LPS contains the single TLR4, rs4986790 mutation and individuals with the haplotype exhibited a strong pro-inflammatory TNF- $a$ cytokine response after stimulation with LPS [123].

A missense SNP of TLR5, rs5744174, resulted in reduced flagellin responsiveness and is associated with improved health in cystic fibrosis adults (a disease that is linked to $P$. aeruginosa colonisation of the lungs) [124]. A non-synonymous polymorphism of TLR5, rs5744168, which encodes a variant that abolishes flagellin-induced signalling, was associated with altered urinary tract infection (UTI) disease intensity and susceptibility [125]. A known TLR-9 SNP, rs5743836, is located within the putative promoter region and may influence transcriptional regulation of the TLR-9 gene [126]. This SNP has been reported to be associated with increased risk of asthma [127].

To date the only study investigating the relation of SNPs in TLRs has examined whether a single SNP in the TLR4 gene (rs4986790) was associated with susceptibility to MK or severity of the disease; no association was found [128]. However, this is only one of many possible SNPs in this gene and there are many SNPS in other TLR genes that could be investigated in future studies [129].

\section{SNPs and the interleukins (IL)-1 $\beta$, IL6, IL8, IL10, and IL12B}

Activation of TLRs by their respective ligands leads to the production of inflammatory cytokines in vivo and in vitro $[118,130$ 132]. A large number of SNPs within the coding and non-coding region of cytokine genes have been identified by various authors and shown to alter the expression of the cytokines and have pathological consequences. These SNPs may lead to increased risk of infections and altered outcome of disorders [120,133,134].

There are many SNPs in the various cytokine and chemokine genes that could be investigated for association with MK. At present the only genes that have been investigated for SNP associations with MK are IL1, IL6, IL10, and IL12. No association between the SNP rs1143627 in the IL1 $\beta$ gene and MK was found in the study of Carnt et al. [135]. The IL6 SNP rs 1800795 has been reported to lower plasma IL-6 levels, increase the risk of developing bladder cancer, and is significantly associated with an increased risk of severe sepsis, and severity of posttraumatic systemic inflammatory response syndrome (SIRS) [136-138]. Carnet et al. found that carriers of IL-6 SNPs were more likely to experience moderate and severe events compared with those with non-mutated genotypes (rs1800795 odds ratio [OR] 6.4. rs1800795/rs1800797: OR, 4.1) [135].

The IL10 SNP, rs6703630 allele A that has been associated with a low IL-10 production was more common in patients with corneal ulcers than controls [134]. The IL10 SNP, rs6693899 allele C, which has been associated high levels of IL-10, was associated with better clinical outcome of contact lens wearers with corneal ulcers [134]. In contrast, allele A of the same promoter SNP was associated with poor clinical outcome [134].

Finally, the IL12B SNP, rs3212227 3'UTR polymorphism has been associated with several diseases related to immune responses, and with variation in the production of IL-12 [139]. This SNP was associated with an increased risk of sterile keratitis (OR, 9.7) compared with controls [135].

\section{Defensins}

The rs5743399 and rs5743409 SNPs and the CT haplotype of these SNPs of the DEFB1 gene are associated with the susceptibility to atopic dermatitis (AD). Furthermore, the rs5743399 polymorphism and the CT haplotype in this gene showed a strong association with the allergic, extrinsic type of atopic dermatitis. The GG genotype of DEFB1 rs1800972 SNP is protective, and much less frequent (4\%) among Crohn's disease patients than controls [140]. The study by Carnt et al. found that carriers of SNPs of DEFB1 rs1799946 or rs11362 showed a trend toward increased susceptibility to keratitis (rs1799946 odds ratio [OR] 1.45; rs11362 OR 1.37) [128]. A DEFB1 promoter haplotype (G-G-A) had a tendency toward decreased susceptibility of MK (OR, 0.68) and reduced severity (OR, 0.56) [128]. At this time there are no other studies examining the association of defensin SNPS with MK.

\section{Conclusion}

Single nucleotide polymorphisms of genes encoding key cell signalling or inflammatory mediators may predispose individuals to have adverse events during CL wear and/or to have increased inflammation during adverse events related to CL wear. A small number of SNPs have been associated with increased susceptibility to $\mathrm{MK}$ and other adverse events with contact lens wear, yet others may be protective. Future studies should screen other SNPs of genes involved in ocular inflammation (such as IL-8, and the TLRs) that might influence keratitis susceptibility or severity and also study the functional analysis of these genes and production of their proteins to confirm these SNP associations. Together, this information might help in identifying patients at risk of developing keratitis with contact lens wear, and in the development of novel prophylactic and/or therapeutic strategies.

\section{References}

1. Aasuri MK, Venkata N, Kumar VM (2003) Differential diagnosis of microbia keratitis and contact lens-induced peripheral ulcer. Eye Contact Lens 29: S60-S62.

2. Stein RM, Clinch TE, Cohen EJ, Genvert GI, Arentsen JJ, et al. (1988) Infected vs sterile corneal infiltrates in contact lens wearers. Am J Ophthalmol 105: 632-636.

3. Sweeney DF, Jalbert I, Covey M, Sankaridurg PR, Vajdic C, et al. (2003) Clinical characterization of corneal infiltrative events observed with soft contact lens wear. Cornea 22: 435-442. 
Citation: Konda N, Willcox MDP. Review of Inflammation and Infection in Contact Lens Wearers: Risk Factors and Association with Single Nucleotide Polymorphisms. J Ocular Biol. 2013;1(2): 9.

4. Cokington CD, Hyndiuk RA (1996) Bacterial keratitis. Boston, Mass: Little, Brown and $\mathrm{Co}$

5. Schein OD, Ormerod LD, Barraquer E, Alfonso E, Egan KM, et al. (1989) Microbiology of Contact Lens-Related Keratitis. Cornea 8: 281-285.

6. Sharma S, Gopalakrishnan S, Aasuri MK, Garg P, Rao GN (2003) Trends in contact lens-associated microbial keratitis in Southern India. Ophthalmology 110: 138-143.

7. Poggio EC, Glynn RJ, Schein OD, Seddon JM, Shannon MJ, et al. (1989) The incidence of ulcerative keratitis among users of daily-wear and extendedwear soft contact lenses. N Eng J Med 321: 779-783.

8. Cheng $\mathrm{KH}$, Leung SL, Hoekman HW, Beekhuis WH, Mulder PG, et al. (1999) Incidence of contact-lens-associated microbial keratitis and its related morbidity. Lancet 354: 181-185.

9. MacRae S, Herman C, Stulting RD, Lippman R, Whipple D, et al. (1991) Corneal ulcer and adverse reaction-rates in premarket contact lens studies. Am J Ophthalmol 111: 457-465.

10. Lam DS, Houang E, Fan DS, Lyon D, Seal D, et al. (2002) Incidence and risk factors for microbial keratitis in Hong Kong: comparison with Europe and North America. Eye 16: 608-618.

11. Sharma S, Garg P, Rao GN (2000) Patient characteristics, diagnosis, and treatment of non-contact lens related Acanthamoeba keratitis. $\mathrm{Br} J$ Ophthalmol 84: 1103-1108.

12. Jeng BH, Gritz DC, Kumar AB, Holsclaw DS, Porco TC, et al. (2010) Epidemiology of ulcerative keratitis in Northern California. Arch Ophthalmo 128: 1022-1028.

13. Willcox MD, Naduvilath TJ, Vaddavalli PK, Holden BA, Ozkan J, et al. (2010) Corneal erosions, bacterial contamination of contact lenses, and microbia keratitis. Eye Contact Lens 36: 340-345.

14. Srinivasan M, Gonzales CA, George C, Cevallos V, Mascarenhas JM, et al. (1997) Epidemiology and aetiological diagnosis of corneal ulceration in Madurai, south India. Br J Ophthalmol 81: 965-971.

15. Green M, Apel A, Stapleton F (2008) Risk Factors and Causative Organisms in Microbial Keratitis. Cornea 27: 22-27.

16. Ly CN, Pham JN, Badenoch PR, Bell SM, Hawkins G, et al. (2006) Bacteria commonly isolated from keratitis specimens retain antibiotic susceptibility to fluoroquinolones and gentamicin plus cephalothin. Clin Experiment Ophthalmol 34: 44-50.

17. Willcox MD, Zhu H, Conibear TC, Hume EB, Givskov M, et al. (2008) Role of quorum sensing by Pseudomonas aeruginosa in microbial keratitis and cystic fibrosis. Microbiology 154: 2184-2194.

18. Willcox MD (2007) Pseudomonas aeruginosa infection and inflammation during contact lens wear: a review. Optom Vis Sci 84: 273-278.

19. Twining SS, Kirschner SE, Mahnke LA, Frank DW (1993) Effect of Pseudomonas aeruginosa elastase, alkaline protease, and exotoxin A on corneal proteinases and proteins. Invest Ophthalmol Vis Sci 34: 2699-2612.

20. O'Callaghan RJ, Engel LS, Hobden JA, Callegan MC, Green LC, et al. (1996) Pseudomonas keratitis. The role of an uncharacterized exoprotein, protease IV, in corneal virulence. Invest Ophthalmol Vis Sci 37: 534-543.

21. Fleiszig SMJ, Evans DJ (2002) The pathogenesis of bacterial keratitis: studies with Pseudomonas aeruginosa. Clin Exp Optom 85: 271-278.

22. Fukuda K, Kumagai N, Yamamoto K, Fujitsu Y, Chikamoto N, et al. (2005) Potentiation of lipopolysaccharide-induced chemokine and adhesion molecule expression in corneal fibroblasts by soluble CD14 or LPS-binding protein. Invest Ophthalmol Vis Sci 46: 3095-3001.

23. Fletcher EL, Fleiszig SM, Brennan NA (1993) Lipopolysaccharide in adherence of Pseudomonas aeruginosa to the cornea and contact lenses. Invest Ophthalmol Vis Sci 34: 1930-1936.

24. Hemmi H, Akira S (2002) A Novel Toll-Like Receptor that Recognizes Bacterial DNA. In: Raz E, editor. Microbial DNA and Host Immunity: Humana Press 39-47.

25. Mah-Sadorra JH, Yavuz SG, Najjar DM, Laibson PR, Rapuano CJ, et al. (2005) Trends in contact lens-related corneal ulcers. Cornea 24: 51-58.
26. Holden BA, Reddy MK, Sankaridurg PR, Buddi R, Sharma S, Willcox MD et al. (1999) Contact lens-induced peripheral ulcers with extended wear of disposable hydrogel lenses: histopathologic observations on the nature and type of corneal infiltrate. Cornea 18: 538-543.

27. Grant T, Chong MS, Vajdic C, Swarbrick HA, Gauthier C, et al. (1998) Contact lens induced peripheral ulcers during hydrogel contact lens wear. CLAO J 24 145-151.

28. Jalbert I, Willcox MD, Sweeney DF (2000) Isolation of Staphylococcus aureus from a contact lens at the time of a contact lens-induced peripheral ulcer: case report. Cornea 19: 116-120.

29. Sankaridurg PR, Sharma S, Willcox M, Sweeney DF, Naduvilath TJ, et al (1999) Colonization of hydrogel lenses with Streptococcus pneumoniae: risk of development of corneal infiltrates. Cornea 18: 289-295

30. Wu P, Stapleton F, Willcox MD (2003) The causes of and cures for contact lens-induced peripheral ulcer. Eye Contact Lens 29: S63-S66.

31. Baum J, Dabezies OH Jr (2000) Pathogenesis and treatment of "sterile" midperipheral corneal infiltrates associated with soft contact lens use. Cornea 19: $777-781$.

32. Sankaridurg PR, Sweeney DF, Sharma S, Gora R, Naduvilath T, et al. (1999) Adverse events with extended wear of disposable hydrogels: results for the first 13 months of lens wear. Ophthalmology 106: 1671-1680.

33. Holden BA, La Hood D, Grant T, Newton-Howes J, Baleriola-Lucas C, et al (1996) Gram-negative bacteria can induce contact lens related acute red eye (CLARE) responses. CLAO J 22: 47-52.

34. Sankaridurg PR, Sharma S, Willcox M, Naduvilath TJ, Sweeney DF, et al. (2000) Bacterial colonization of disposable soft contact lenses is greater during corneal infiltrative events than during asymptomatic extended lens wear. J Clin Microbiol 38: 4420-4424.

35. Thakur A, Willcox MD (2000) Contact lens wear alters the production of certain inflammatory mediators in tears. Exp Eye Res 70: 255-259.

36. Tan KO, Sack RA, Holden BA, Swarbrick HA (1993) Temporal sequence of changes in tear film composition during sleep. Curr Eye Res 12: 1001-1007.

37. Willcox MD, Hume EB (1999) Differences in the pathogenesis of bacteria isolated from contact-lens-induced infiltrative conditions. Austr $\mathrm{N} Z \mathrm{~J}$ Ophthalmol 27: 231-233.

38. Sweeney DF, Stern J, Naduvilath T, Holden BA (2002) Inflammatory adverse event rates over 3 years with Silicone Hydrogel lenses. Invest Ophthalmol Vis Sci 43: 976.

39. Dumbleton K (2002) Adverse events with silicone hydrogel continuous wear Cont Lens Anterior Eye 25: 137-146.

40. Stapleton F, Keay L, Jalbert I, Cole N (2007) The epidemiology of contact lens related infiltrates. Optom Vis Sci 84: 257-272.

41. Dumbleton K (2002) Adverse events with silicone hydrogel continuous wear. Cont Lens Anterior Eye 25: 137-146.

42. Dart JK, Stapleton F, Minassian D (1991) Contact lenses and other risk factors in microbial keratitis. Lancet 338: 650-653.

43. Edwards K, Keay L, Naduvilath T, Snibson G, Taylor H, et al. (2009) Characteristics of and risk factors for contact lens-related microbial keratitis in a tertiary referral hospital. Eye (Lond) 23: 153-160.

44. Efron N, Wohl A, Toma NG, Jones LWJ, Lowe R (1991) Pseudomonas corneal ulcers associated with daily wear of disposable hydrogel contact lenses. ICLC 18: 46-52

45. Keay L, Edwards K, Naduvilath T, Forde K, Stapleton F (2006) Factors affecting the morbidity of contact lens-related microbial keratitis: a population study. Invest Ophthalmol Vis Sci 47: 4302-4308.

46. Keay L, Edwards K, Stapleton F (2009) Signs, symptoms, and comorbidities in contact lens-related microbial keratitis. Optom Vis Sci 86: 803-809.

47. Wong T, Ormonde S, Gamble G, McGhee CN (2003) Severe infective keratitis leading to hospital admission in New Zealand. Br J Ophthalmol 87: 1103-1108.

48. Dart JK, Radford CF, Minassian D, Verma S, Stapleton F (2008) Risk factors for microbial keratitis with contemporary contact lenses: a case-control study. Ophthalmology 115: 1647-1654. 
Citation: Konda N, Willcox MDP. Review of Inflammation and Infection in Contact Lens Wearers: Risk Factors and Association with Single Nucleotide Polymorphisms. J Ocular Biol. 2013;1(2): 9.

49. Stapleton F, Keay L, Edwards K, Naduvilath T, Dart JK, et al. (2008) The incidence of contact lens-related microbial keratitis in Australia Ophthalmology 115: 1655-1662.

50. Stapleton F, Edwards K, Keay L, Naduvilath T, Dart JK, et al. (2012) Risk factors for moderate and severe microbial keratitis in daily wear contact lens users. Ophthalmology 119: 1516-1521.

51. Chang DC, Grant GB, O’Donnell K, Wannemuehler KA, Noble-Wang J, et al. (2006) Multistate outbreak of Fusarium keratitis associated with use of a contact lens solution. JAMA 296: 953-963.

52. Joslin CE, Tu EY, Shoff ME, Booton GC, Fuerst PA, et al. (2007) The association of contact lens solution use and Acanthamoeba keratitis. Am J Ophthalmol 144: 169-180.

53. Holden BA, Sweeney DF, Sankaridurg PR, Carnt N, Edwards K, et al. (2003) Microbial Keratitis and Vision Loss with Contact Lenses. Eye Contact Lens 29: S131-S134.

54. Nilsson SE, Montan PG (1994) The annualized incidence of contact lens induced keratitis in Sweden and its relation to lens type and wear schedule: results of a 3-month prospective study. CLAO J 20: 225-230.

55. Solomon OD, Loff H, Perla B, Kellis A, Belkin J, et al. (1994) Testing hypotheses for risk factors for contact lens-associated infectious keratitis in an animal model. CLAO J 20: 109-113.

56. Sankaridurg PR, Sweeney DF, Holden BA, Naduvilath T, Velala I, et al. (2003) Comparison of adverse events with daily disposable hydrogels and spectacle wear: results from a 12-month prospective clinical trial. Ophthalmology 110 2327-2334.

57. Nilsson SE (2001) Seven-day extended wear and 30-day continuous wear of high oxygen transmissibility soft silicone hydrogel contact lenses: randomized 1-year study of 504 patients. CLAO J 27: 125-136.

58. Schein OD, McNally JJ, Katz J, Chalmers RL, Tielsch JM, et al. (2005) The incidence of microbial keratitis among wearers of a 30-day silicone hydrogel extended-wear contact lens. Ophthalmology 112: 2172-2179.

59. Gopinathan U, Stapleton F, Sharma S, Willcox MD, Sweeney DF, et al. (1997) Microbial contamination of hydrogel contact lenses. J Appl Microbio 82: 653-658.

60. Radford CF, Minassian D, Dart JK, Stapleton F, Verma S (2009) Risk factors for nonulcerative contact lens complications in an ophthalmic accident and emergency department: a case-control study. Ophthalmology 116: 385-392.

61. Ozkan J, Mandathara P, Krishna P, Sankaridurg P, Naduvilath T, et al. (2010) Risk factors for corneal inflammatory and mechanical events with extended wear silicone hydrogel contact lenses. Optom Vis Sci 87: 847-853.

62. McNally JJ, Chalmers RL, McKenney CD, Robirds S (2003) Risk factors for corneal infiltrative events with 30-night continuous wear of silicone hydrogel lenses. Eye Contact Lens 29: S153-S156.

63. Vijay AK, Sankaridurg P, Zhu H, Willcox MD (2009) Guinea pig models of acute keratitis responses. Cornea 28: 1153-1159.

64. Zhang Y, Gabriel MM, Mowrey-McKee MF, Barrett RP, McClellan S, et al (2008) Rat silicone hydrogel contact lens model: effects of high- versus lowDk lens wear. Eye Contact Lens 34: 306-311.

65. Tam C, Mun JJ, Evans DJ, Fleiszig SM (2010) The impact of inoculation parameters on the pathogenesis of contact lens-related infectious keratitis. Invest Ophthalmol Vis Sci 51: 3100-3106.

66. Akira S, Takeda K (2004) Toll-like Receptor Signalling. Nat Rev Immunol 4: 499-511.

67. Gay NJ, Gangloff M (2007) Structure and function of toll receptors and their ligands. Ann Rev Biochem 76: 141-165.

68. Takeda K, Kaisho T, Akira S (2003) Toll-like receptors. Ann Rev Immunol 21: 335-376.

69. Hemmi H, Takeuchi O, Kawai T, Kaisho T, Sato S, et al. (2000) A Toll-like receptor recognizes bacterial DNA. Nature 408: 740-745.

70. Ueta M, Nochi T, Jang MH, Park EJ, Igarashi O, et al. (2004) Intracellularly expressed TLR2s and TLR4s contribution to an immunosilent environment at the ocular mucosal epithelium. J Immunol 173: 3337-3347.

71. Kumar A, Zhang J, Yu FS (2006) Toll-like receptor 2-mediated expression of beta-defensin-2 in human corneal epithelial cells. Microbes Infect 8: 380-389.
72. Johnson AC, Heinzel FP, Diaconu E, Sun Y, Hise AG, et al. (2005) Activation of toll-like receptor (TLR)2, TLR4, and TLR9 in the mammalian cornea induces MyD88-dependent corneal inflammation. Invest Ophthalmol Vis Sci 46: $589-595$

73. Song PI, Abraham TA, Park Y, Zivony AS, Harten B, et al. (2001) The expression of functional LPS receptor proteins CD14 and toll-like receptor 4 in human corneal cells. Invest Ophthalmol Vis Sci 42: 2867-2877.

74. Solomon A, Rosenblatt M, Li DQ, Liu Z, Monroy D, et al. (2000) Doxycycline inhibition of interleukin-1 in the corneal epithelium. Invest Ophthalmol Vis Sci 41: 2544-2557.

75. Takeuchi O, Hoshino K, Kawai T, Sanjo H, Takada H, et al. (1999) Differential roles of TLR2 and TLR4 in recognition of gram-negative and gram-positive bacterial cell wall components. Immunity 11: 443-451.

76. Dobrovolskaia MA, Medvedev AE, Thomas KE, Cuesta N, Toshchakov V, et al. (2003) Induction of in vitro reprogramming by toll-like receptor (TLR)2 and TLR4 agonists in murine macrophages: effects of TLR "homotolerance" versus "heterotolerance" on NF-\{kappa\}B signaling pathway components. J Immunol 170: 508-519.

77. Arbour NC, Lorenz E, Schutte BC, Zabner J, Kline JN, et al. (2000) TLR4 mutations are associated with endotoxin hyporesponsiveness in humans. Nat Genet 25: 187-191.

78. Shimazu R, Akashi S, Ogata H, Nagai Y, Fukudome K, et al. (1999) MD2 , a molecule that confers lipopolysaccharide responsiveness on Toll-like receptor 4. J Exp Med 189: 1777-1782.

79. Poltorak A, He X, Smirnova I, Liu MY, Van Huffel C, et al. (1998) Defective LPS signaling in $\mathrm{C} 3 \mathrm{H} / \mathrm{HeJ}$ and $\mathrm{C} 57 \mathrm{BL} / 10 \mathrm{ScCr}$ mice: mutations in $\mathrm{Tl} 4 \mathrm{~g}$ gene. Science 282: 2085-2088

80. Huang X, Hazlett LD, Du W, Barrett RP (2006) SIGIRR promotes resistance against pseudomonas aeruginosa keratitis by down-regulating Type-1 immunity and IL-1R1 and TLR4 signaling. J Immunol 177: 548-556.

81. Huang X, Du W, Barrett RP, Hazlett LD (2007) ST2 is essential for Th2 responsiveness and resistance to Pseudomonas aeruginosa keratitis. Invest Ophthalmol Vis Sci 48: 4626-4633.

82. Hayashi F, Smith KD, Ozinsky A, Hawn TR, Yi EC, et al. (2001) The innate immune response to bacterial flagellin is mediated by Toll-like receptor 5 . Nature 410: 1099-1003

83. Zhang J, Xu K, Ambati B, Yu FS (2003) Toll-like receptor 5-mediated corneal epithelial inflammatory responses to Pseudomonas aeruginosa flagellin. Invest Ophthalmol Vis Sci 44: 4247-4254.

84. Tallant T, Deb A, Kar N, Lupica J, de Veer M, et al. (2004) Flagellin acting via TLR5 is the major activator of key signaling pathways leading to NF-kappaB and proinflammatory gene program activation in intestinal epithelial cells. BMC Microbiol 4: 33.

85. Hasan M, Lopez-Herrera G, Blomberg KE, Lindvall JM, Berglof A, et al (2008) Defective Toll-like receptor 9-mediated cytokine production in B cells from Bruton's tyrosine kinase-deficient mice. Immunology 123: 239-249.

86. Krug A, Towarowski A, Britsch S, Rothenfusser S, Hornung V, et al. (2001) Toll-like receptor expression reveals CpG DNA as a unique microbial stimulus for plasmacytoid dendritic cells which synergizes with CD40 ligand to induce high amounts of IL-12. Eur J Immunol 31: 3026-3037.

87. Willcox MD, Lan J (1999) Secretory immunoglobulin A in tears: functions and changes during contact lens wear. Clin Exp Optom 82: 1-3.

88. Rudner XL, Kernacki KA, Barrett RP, Hazlett LD (2000) Prolonged elevation of IL-1 in Pseudomonas aeruginosa ocular infection regulates macrophageinflammatory protein-2 production, polymorphonuclear neutrophil persistence, and corneal perforation. J Immunol 164: 6576-6582.

89. Xue ML, Wakefield D, Willcox MD, Lloyd AR, Di Girolamo N, et al. (2003) Regulation of MMPs and TIMPs by IL-1 $\beta$ during corneal ulceration and infection. Invest Ophthalmol Vis Sci 44: 2020-2025.

90. Thakur A, Barrett RP, Hobden JA, Hazlett LD (2004) Caspase-1 inhibitor reduces severity of Pseudomonas aeruginosa keratitis in mice. Invest Ophthalmol Vis Sci 45: 3177-3184.

91. Thakur A, Barrett R, McClellan S, Hazlett LD (2004) Regulation of Pseudomonas aeruginosa corneal infection in IL-1beta converting enzyme (ICE, caspase-1) deficient mice. Curr Eye Res 29: 225-233. 
Citation: Konda N, Willcox MDP. Review of Inflammation and Infection in Contact Lens Wearers: Risk Factors and Association with Single Nucleotide Polymorphisms. J Ocular Biol. 2013;1(2): 9.

92. Cole N, Bao S, Willcox M, Husband AJ (1999) Expression of interleukin-6 in the cornea in response to infection with different strains of Pseudomonas aeruginosa. Infect Immun 67: 2497-2502.

93. Cole N, Krockenberger M, Stapleton F, Khan S, Hume E, et al. (2003) Experimental Pseudomonas aeruginosa keratitis in interleukin-10 gene knockout mice. Infect Immun 71: 1328-1336.

94. Cole N, Krockenberger M, Bao S, Beagley KW, Husband AJ, et al. (2001) Effects of exogenous interleukin-6 during Pseudomonas aeruginosa corneal infection. Infect Immun 69: 4116-4119.

95. Hume EB, Cole N, Garthwaite LL, Khan S, Willcox MD (2006) A protective role for IL-6 in staphylococcal microbial keratitis. Invest Ophthalmol Vis Sci 47: 4926-4930.

96. Thakur A, Willcox MD (1998) Cytokine and lipid inflammatory mediator profile of human tears during contact lens associated inflammatory diseases. Exp Eye Res 67: 9-19.

97. Thakur A, Willcox MD (1998) Chemotactic activity of tears and bacteria isolated during adverse responses. Exp Eye Res 66: 129-137.

98. Thakur A, Xue M, Stapleton F, Lloyd AR, Wakefield D, et al. (2002) Balance of pro- and anti-inflammatory cytokines correlates with outcome of acute experimental Pseudomonas aeruginosa keratitis. Infect Immun 70: 21872197.

99. Huang LC, Reins RY, Gallo RL, McDermott AM (2007) Cathelicidin-deficient (Cnlp-/-) mice show increased susceptibility to Pseudomonas aeruginosa keratitis. Invest Ophthalmol Vis Sci 48: 4498-4408

100. Redfern RL, Reins RY, McDermott AM (2011) Toll-like receptor activation modulates antimicrobial peptide expression by ocular surface cells. Exp Eye Res 92: 209-220.

101. Kumar A, Yin J, Zhang J, Yu FS (2007) Modulation of corneal epithelia innate immune response to pseudomonas infection by flagellin pretreatment. Invest Ophthalmol Vis Sci 48: 4664-4670.

102. van Wetering S, Mannesse-Lazeroms SP, van Sterkenburg MA, Hiemstra PS (2002) Neutrophil defensins stimulate the release of cytokines by airway epithelial cells: modulation by dexamethasone. Inflamm Res 51: 8-15

103. Niyonsaba F, Hirata M, Ogawa H, Nagaoka I (2003) Epithelial cell-derived antibacterial peptides human beta-defensins and cathelicidin: multifunctional activities on mast cells. Curr Drug Targets Inflamm Allergy 2: 224-231.

104. Huang LC, Petkova TD, Reins RY, Proske RJ, McDermott AM (2006) Multifunctional roles of human cathelicidin (LL-37) at the ocular surface. Invest Ophthalmol Vis Sci 47: 2369-2380.

105. Alonzi T, Fattori E, Lazzaro D, Costa P, Probert L, et al. (1998) Interleukin 6 is required for the development of collagen-induced arthritis. J Exp Med 187 461-468.

106. Andia DC, de Oliveira NF, Letra AM, Nociti FH Jr, Line SRP, et al. (2011) Interleukin-8 gene promoter polymorphism (rs4073) may contribute to chronic periodontitis. J Periodontol 82: 893-899.

107. Bergholdt R, Ghandil P, Johannesen J, Kristiansen OP, Kockum I, et al (2004) Genetic and functional evaluation of an interleukin-12 polymorphism (IDDM18) in families with type 1 diabetes. J Med Genet 41: e39.

108. Bustamante J, Tamayo E, Florez S, Telleria JJ, Bustamante E, et al. (2011) Toll-like receptor $2 \mathrm{R} 753 \mathrm{Q}$ polymorphisms are associated with an increased risk of infective endocarditis. Rev Esp Cardiol 64: 1056-1059.

109. Chen J, Liu RY, Yang L, Zhao J, Zhao X, et al. (2013) A two-SNP IL-6 promoter haplotype is associated with increased lung cancer risk. J Cancer Res Clin Oncol 139: 231-242.

110. Claudino M, Trombone APF, Cardoso CR, Ferreira SB Jr, Martins W Jr, et al (2008) The broad effects of the functional IL-10 promoter-592 polymorphism: modulation of IL-10, TIMP-3, and OPG expression and their association with periodontal disease outcome. J Leukoc Biol 84: 1565-1573.

111.El-Omar EM, Carrington M, Chow WH, McColl KE, Bream JH, et al. (2000) Interleukin-1 polymorphisms associated with increased risk of gastric cancer. Nature 404: 398-402.

112. Cirulli ET, Goldstein DB (2010) Uncovering the roles of rare variants in common disease through whole-genome sequencing. Nat Rev Genet 11: 415-425.
113. Bodmer W, Bonilla C (2008) Common and rare variants in multifactorial susceptibility to common diseases. Nat Genet 40: 695-701.

114. Schork NJ, Murray SS, Frazer KA, Topol EJ (2009) Common vs. rare allele hypotheses for complex diseases. Curr Opin Genet Dev 19: 212-219.

115. Goate A, Chartier-Harlin MC, Mullan M, Brown J, Crawford F, et al. (1991) Segregation of a missense mutation in the amyloid precursor protein gene with familial Alzheimer's disease. Nature 349: 704-706.

116. van der Pouw Kraan TC, van Veen A, Boeije LC, van Tuyl SA, de Groot ER et al. (1999) An IL-13 promoter polymorphism associated with increased risk of allergic asthma. Genes Immun 1: 61-65.

117. Brookes AJ (1999) The essence of SNPs. Gene 234: 177-186

118. Lorenz E, Mira JP, Cornish KL, Arbour NC, Schwartz DA (2000) A nove polymorphism in the toll-like receptor 2 gene and its potential association with staphylococcal infection. Infect Immun 68: 6398-6301.

119. Kutukculer N, Yeniay B, Aksu G, Berdeli A (2007) Arg753GIn polymorphism of the human toll-like receptor-2 gene in children with recurrent febrile infections. Biochem Genet 45: 507-514.

120.Smith AJ, Humphries SE (2009) Cytokine and cytokine receptor gene polymorphisms and their functionality. Cytokine Growth Factor Rev 20: 4359

121. Read RC, Pullin J, Gregory S, Borrow R, Kaczmarski EB, et al. (2001) A functional polymorphism of toll-like receptor 4 is not associated with likelihood or severity of meningococcal disease. J Infect Dis 184: 640-642.

122. Lorenz E, Mira JP, Frees KL, Schwartz DA (2002) Relevance of mutations in the TLR4 receptor in patients with gram-negative septic shock. Arch Intern Med 162: 1028-1032.

123. Ferwerda B, McCall MBB, Alonso S, Giamarellos-Bourboulis EJ, Mouktaroud $M$, et al. (2007) TLR4 polymorphisms, infectious diseases, and evolutionary pressure during migration of modern humans. Proc Nat Acad Sci U S A 104: 16645-16650.

124. Blohmke CJ, Park J, Hirschfeld AF, Victor RE, Schneiderman J, et al. (2010) TLR5 as an anti-inflammatory target and modifier gene in cystic fibrosis. $J$ Immunol 185: 7731-7738.

125. Hawn TR, Scholes D, Li SS, Wang H, Yang Y, et al. (2009) Toll-like receptor polymorphisms and susceptibility to urinary tract infections in adult women. PLoS One 4: e5990.

126. Lazarus R, Klimecki WT, Raby BA, Vercelli D, Palmer LJ, et al. (2003) Single-nucleotide polymorphisms in the Toll-like receptor 9 gene (TLR9): frequencies, pairwise linkage disequilibrium, and haplotypes in three U.S. ethnic groups and exploratory case-control disease association studies. Genomics 81: 85-91.

127. Lange N, Zhou X, Lasky-Su J, Himes B, Lazarus R, et al. (2011) Comprehensive genetic assessment of a functional TLR9 promoter polymorphism: no replicable association with asthma or asthma-related phenotypes. BMC Med Genet 12: 26.

128. Carnt NA, Willcox MD, Hau S, Keay L, Dart JK, et al. (2012) Immune defense single nucleotide polymorphisms and recruitment strategies associated with contact lens keratitis. Ophthalmology 119: 1997-2002.

129. Georgel P, Macquin C, Bahram S (2009) The heterogeneous allelic repertoire of human toll-like receptor (TLR) genes. PloS One 4: e7803.

130. Mrabet-Dahbi S, Dalpke AH, Niebuhr M, Frey M, Draing C, et al. (2008) The Toll-like receptor $2 \mathrm{R} 753 \mathrm{Q}$ mutation modifies cytokine production and Toll-like receptor expression in atopic dermatitis. J Allergy Clin Immunol 121: 1013-1019.

131. Fagerås Böttcher $M$, Hmani-Aifa $M$, Lindström $A$, Jenmalm $M C$, Mai $X M$ et al. (2004) A TLR4 polymorphism is associated with asthma and reduced lipopolysaccharide-induced interleukin-12(p70) responses in Swedish children. J Allergy Clin Immunol 114: 561-567.

132. Im J, Jeon JH, Cho MK, Woo SS, Kang SS, et al. (2009) Induction of IL-8 expression by bacterial flagellin is mediated through lipid raft formation and intracellular TLR5 activation in A549 cells. Mol Immunol 47: 614-622.

133. Hull J, Thomson A, Kwiatkowski D (2000) Association of respiratory syncytial virus bronchiolitis with the interleukin 8 gene region in UK families. Thorax 55: 1023-1027. 
Citation: Konda N, Willcox MDP. Review of Inflammation and Infection in Contact Lens Wearers: Risk Factors and Association with Single Nucleotide Polymorphisms. J Ocular Biol. 2013;1(2): 9.

134. Keijser S, Kurreeman FA, de Keizer RJ, Dogterom-Ballering H, van der Lelij A, et al. (2009) IL-10 promotor haplotypes associated with susceptibility to and severity of bacterial corneal ulcers. Exp Eye Res 88: 1124-1128.

135. Carnt NA, Willcox MD, Hau S, Garthwaite LL, Evans VE, et al. (2012 Association of single nucleotide polymorphisms of interleukins-1 $\beta,-6$, and $-12 \mathrm{~B}$ with contact lens keratitis susceptibility and severity. Ophthalmology 119: $1320-1327$

136. Fishman D, Faulds G, Jeffery R, Mohamed-Ali V, Yudkin JS, et al. (1998) The effect of novel polymorphisms in the interleukin-6 (IL-6) gene on IL-6 transcription and plasma IL-6 levels, and an association with systemic-onset juvenile chronic arthritis. J Clin Invest 102: 1369-1376.
137. Terry CF, Loukaci V, Green FR (2000) Cooperative influence of genetic polymorphisms on interleukin 6 transcriptional regulation. J Biol Chem 275 : 18138-18144.

138. Leibovici D, Grossman HB, Dinney CP, Millikan RE, Lerner S, et al. (2005) Polymorphisms in inflammation genes and bladder cancer: from initiation to recurrence, progression, and survival. J Clin Oncol 23: 5746-5756.

139. Morahan G, Kaur G, Singh M, Rapthap CC, Kumar N, et al. (2007) Association of variants in the IL12B gene with leprosy and tuberculosis. Tissue Antigens 69: 234-236.

140. Kocsis AK, Lakatos PL, Somogyvári F, Fuszek P, Papp J, et al. (2008) Association of beta-defensin 1 single nucleotide polymorphisms with Crohn's disease. Scand J Gastroenterol 43: 299-207. 